\title{
Med rom for flere stemmer? \\ En kritisk analyse av tre nye lareverk for konfirmantundervisning i Den norske kirke
}

\begin{abstract}
Av Bernd Krupka
Artikkelen undersøker tre nye lareverk for konfirmasjonsundervisning i Den norske kirke med kriterier hentet fra larebokanalyse. Fokuset ligger på flerstemmigheten i det fremstilte materialet: Flerstemmighet $i$ innhold presentert $i$ håndbøkene, mangfoldet $i$ representasjonen av konfirmanter og deres egne religiøse praksiser, og stimuleringen av flerstemmighet $i$ samtale og undervisning. Flerstemmighet fremstår ikke som et viktig anliggende i de undersøkte lareverk. Fri meningsutveksling blant konfirmanter er til dels ikke tilsiktet $i$ det hele tatt, til dels begrenset innenfor rammene av en grunnleggende tilslutning til tradisjonell kirkelig lare. Lareverkene lager spirituelle og rituelle praksiser som er spesifikke for konfirmantåret, heller enn å representere konfirmantenes egen religiøse praksis. Lœreverkene førsøker å understreke gyldigheten av kristen lare gjennom rituelle og spirituelle praksiser, heller enn å legge opp til en debatt der flere synspunkt blir synlig. Undervisningsforslagene kombinerer $i$ hovedsak fiktive tekster med bibelske referanser og skaper på den måten et narrativt univers som er atskilt fra hverdagslivet, men også fra aktuelle teologiske og etiske problemstillinger. Det diskuteres avslutningsvis kort om dette narrative universet kan ha sin forankring i kristent ungdomsarbeid som pedagogisk provins i en avstand fra voksenverden.
\end{abstract}

Nøkkelord: konfirmasjon, lærerveiledning, tekstbokanalyse, konfirmantbok, flerstemmighet, kristen praksis, ungdom

BERND KRUPKA (f.1962), førsteamanuensis i religionspedagogikk, Kirkelig utdanningssenter nord. Breivika, 9037 Tromsø. E-post: bernd.krupka@kun.uit.no

\section{INNLEDNING}

Tiden er over, da konfirmanter over hele landet ukentlig benket seg inn i menighetssal, bedehus, kirke eller skole for 45 eller 90 minutters konfirmantundervisning. Ikke fordi konfirmasjon har blitt upopulær, men fordi konfirmantundervisningen er inne i et hamskifte fra en skolepreget til en ungdomsarbeidspreget samværsform (Niemelä/Ilg 2015, Innanen/Krupka 2013). I 2013 samlet norske konfirmanter seg gjennomsnittlig 18 ganger i løpet av konfirmantåret, utenom gudstjenestene (se Schweitzer/Niemelä/Schlag/Simojoki 2015). Ukentlige samlinger er med andre ord mer unntaket enn regelen i norsk konfirmantundervisning.

For å bruke en konfirmantbok trenger man gjerne også et bord og en stol, og

Prismet - IKO-Forlaget 2018

Tilgjengelig på https://journals.uio.no/index.php/prismet. Publisert under CC BY-NC 4.0. 
én eller annen form for tavle og skriveredskaper. En konfirmantbok gir mening når konfirmantåret er lagt opp forholdsvis 'skolsk', men ikke når man har et mangfold av arbeids- og sosialformer. Antall utgivelser av konfirmantbok og typer konfirmantmateriell opp igjennom årene er deretter. For tidsrommet 1999 til 2007 gir kateket Edgar Bostrøm (2007) en oversikt over konfirmantbøker og -materiale utgitt for konfirmasjon i Den norske kirke og andre trossamfunn. Han konkluderer med at «oppleggene har blitt mindre omfattende de siste årene.» (153).

Det er derfor interessant at det nylig har kommet ut tre nye konfirmantopplegg av en mer omfattende karakter: Konfirmantbibelen, en bibelutgave med et katekisme-tillegg i to deler, kom i ny omarbeidet utgave i 2013리 og i $2015 \mathrm{kom}$ lærerveiledningen i en omfattende andre utgave (Leganger-Krogstad m.fl. 2015). I 2015 (andre opplag 2016) kom også konfirmantopplegget Delta (Midtsund, Liodden 2016), utgitt hos IKO, og opplegget Nøkler til livet - nye metoder for laering $i$ kirken, utgitt av KFUK-KFUM ved Jan Christian Kielland (2015). Sistnevnte bok er ikke bare, men også, tenkt for konfirmantundervisning.

Denne artikkelen skal innledningsvis presentere læreverkene kort, for så å gi en gjennomgang av relevant lærebokanalyse. Lærebokanalysens kriterier og deres gyldighet i en konfirmantundervisningssammenheng blir kort drøftet, for så å anvende dem i analysen av lærebøkene. De konkrete forskningsspørsmål blir formulert etter denne innledende drøftingen.

Alle tre læreverk tilbyr digital støtte, enten online (kbibel.no, nøklertillivet. no) eller som en minnepenn med digitalt undervisningsmateriell (Delta). Ingen av dem ligner på 90-tallets konfirmantbøker som gjerne var rikt illustrerte og dyrt produserte lærebøker. Ellers er de tre læremidler nokså forskjellige:

Av de tre nye er det kun Delta som gir konfirmantene en egen arbeidsbok i hånda. Arbeidsboken, kalt Konflogg (Midtsund 2015), er et innbundet arbeidshefte med et kort sammendrag av undervisningsenheten samt plass til å skrive logg og svare på spørsmål knyttet til det. Lærerveiledningen inneholder en veiledningsdel på ca. 20 sider, 20 ferdig utarbeidete moduler på 117 sider og et par sider med kopieringsoriginaler. Minnepennen inneholder powerpoints og filmsnutter. Det som skiller Delta fra de andre to opplegg, er at alle enheter er bygd over nøyaktig samme lest. Det går også an å bestille et matchende sett med bønnekort.

Ved siden av nevnte bibelutgave og online-ressursen byr Konfirmantbibelen på en tykk lærerveiledning på 286 sider. Den inneholder en faglig innledning på 95 sider, Skisser for 36 temasamlinger på til sammen 107 sider, en seksjon på 74 sider kalt ressurser som samler forklaringer, metodiske tips, kopieringsoriginaler og diverse andre. På slutten finnes det en meget solid litteraturliste.

1 Første utgave i 2002, med veilederhefte ved Rolf Steffensen og Randi Langkaas, (Kittelsen 2010, 38).

Konfirmantbibelen 2013 vant merket for godt design og gull i kåringen av årets vakreste bok i 2013. 
Nøkler til livet har ikke noe håndfast til å dele ut til konfirmanten i det hele tatt. Den trykte delen er en lederveiledning på 176 sider. Av disse er 47 sider faglig innledning i en eller annen form, 124 inneholder opplegg for 26 samlinger av forskjellig lengde (45-120 min). En ressursdel på 4 sider på slutten inneholder en veldig kort oppskrift for en konfirmantgudstjeneste som bruker elementer fra samlingene, samt henvisninger til KFUM/Ks nettressurser.

\section{LITT OM LEREBOKANALYSE}

Lærebokanalyse er en egen gren i pedagogisk forskning. Weinbrenner (1992) gir en omfattende oversikt over lærebokanalyse som siden har ofte blitt sitert. Grunnleggende er et skille mellom innholdsrelatert analyse og didaktisk analyse.

Innholdsrelatert analyse går i sin enkleste form ut på spørsmålet om innholdet i en lærebok er fremstilt korrekt. Men det stopper ikke der. Morgan og Henning (2013) for eksempel videreutvikler innholdsrelatert analyse. I deres analyse av lærebøker i historie i $\oint \emptyset$-Afrika unders $\emptyset$ ker redskapet hvilke føringer læreb $\emptyset$ ker gir (gjennom valg av begrep, identifikasjonstilbud osv.) for elevenes tilegnelse av stoffet.

Didaktisk analyse av lærebøker spør i sin enkleste form etter hvilke metoder og fremstillingsmåter en lærebok bruker, og hvor godt de er tilpasset elevene. Tabari og Tabari (2015) unders $ø$ ker for eksempel metodisk variasjon i læreb $\emptyset$ ker for språk ved hjelp av Gardners teori om forskjellige intelligenser. (om Gardner se Konfirmantbibelen, Lærerveiledning s.65).

Hvordan virkeligheten fremstilles i en lærebok, har politiske implikasjoner. UNESCO har gitt ut en egen veileder for lærebokanalyse og -revisjon. For å unngå å konstruere én monolittisk autorisert versjon av sannhet som marginaliserer andre syn, bør det presenteres forskjellige kilder og faglige stemmer (Pingel 2010:37-45). UNESCOs veileder gjelder lærebøker i nasjonal historie og litteratur. Den er også relevant for lærebøker i religion, siden religion handler i minst like mye grad om verdier, livssyn og verdenssyn som historie og nasjonalt språk og litteratur. Ikke overraskende er også lærebøker i religion gjenstand for kritiske lærebokanalyser (Se Andreassen (2014) for litteratur).

Religion og kristendom er et felles anliggende for konfirmantundervisning og skolens religionsundervisning. I en analyse av lærebøker i RLE-faget i 2008 presenterer Geir Winje et elevrelatert kriterium for ivaretakelsen av religiøst mangfold og likevekt mellom forskjellige perspektiver: «Skal alle norske elever - uansett tros- og livssynstilhørighet - oppleve KRL som 'sitt fag', må bilder, fortellinger, brødtekst og andre elementer gi mening og gjenkjennelse.» (2008:4) Dette handler ikke bare om forskjell mellom religioner, men også om forskjell i religiøs praksis innenfor én og samme religion, ikke minst forskjell i kristen praksis. Skal elevene føle seg hjemme i faget, bør elever med forskjellig 
religiøs praksis i hjemmet kunne kjenne seg igjen.

Bengt-Ove Andreassen har utgitt boken «Textbook Gods», en antologi med lærebokanalyser i religionsvitenskapelig perspektiv. Andreassen argumenterer at lærebøker tillegges en autoritet av brukerne, både profesjonelle, elever og foreldre. Læreb $ø$ ker i religion innf $ø$ rer og befester forestillinger om en lærebokkristendom eller en lærebok-islam, en religionsversjon som ikke nødvendigvis er identisk med levde versjoner av religionen. Slik sett «representerer læreb $\emptyset-$ ker konkretiseringer av makt.» (2014:2f.) Dette utgjør et dilemma: lærebøker må presentere et utvalg av stoff som er relevant for elevenes fremtid, de må foreta en verdibasert konstruksjon av en lærebok-religion. Andreassen nevner også noen eksterne faktorer som understreker lærebokens autoritet, som for eksempel at forfatterne presenteres som eksperter på fagfeltet eller som drevne undervisningspraktikere med lang fartstid, eller at selve utbredelsen av læreboken og opplagstall blir presentert som et kvalitetstegn.

\section{Flerstemmighet Som fellesnevner}

Sett under ett spiller flerstemmighet en sentral rolle i de nevnte tilnærmingene til lærebokanalyse. En flerstemmighet av kilder (Pingel 2010) anbefales som en motvekt til fremskriving av en monolittisk og autorisert versjon av virkeligheten. Det samme gjelder en flerstemmighet av faglige perspektiv. Det gjelder også representasjon av forskjellige egne standpunkter og tradisjoner blant elevene (Winje 2008) - samt didaktisk flerstemmighet i form av metodisk mangfold (Weinbrenner 1992, jf. Tabari \&Tabari 2015), for å tilpasse forskjellige læringsformer til elevene. Flerstemmighet må i dette forstås som flerstemmighet mellom religionene, men også som flerstemmighet mellom forskjellige tradisjoner i en og samme religion (Winje 2008). Andreassen understreker at lærebøker per se ikke unngår å konstruere og autorisere, og gir implisitt noen kriterier for å skille mellom nødvendig og problematisk autorisering av innhold.

Gjelder kvalitetskriterier for en skolebok også for konfirmantundervisningens læreb $\varnothing$ ker? Konfirmantundervisning deler to forutsetninger med KRLE-faget. For det første: konfirmantene lever i et mangfold av religioner og livssyn. De aller fleste har medelever som tilhører en annen religion eller et annet livssyn. Alle møter andre religioner i det ungdomsrelaterte medietilbudet. Religiøs flerstemmighet er med andre ord en del av ungdommens religiøse hverdag. For det andre: Konfirmasjon er fortsatt det opplæringstiltaket utenfor skolevesenet med st $ø$ rst oppslutning i samfunnet ( $60 \%$ av alle 15-åringer ble i 2016 konfirmert i Den norske kirke. Tall: SSB). Det betyr n $\varnothing$ dvendigvis at konfirmanter kommer fra hjem som praktiserer sin kristne tro forskjellig. Religiøs flerstemmighet handler derfor også om forskjellige former for kristen praksis blant konfirmantene. Når den religiøse realiteten for ungdommer generelt og i konfirmantundervisningen 
er lik, bør kvalitetskriteriene også gjelde for konfirmantbøker.

Hva med teologisk funderte kvalitetskriterier for en konfirmantbok? Uten å kunne diskutere dette utførlig kan det fastslås at en viss flerstemmighet innenfor den kristne tradisjonen har lenge hatt en teologisk-hermeneutisk verdi. Biskopenes preses Helga Byfuglien i Den norske kirke skriver i en kronikk i Aftenposten den 22.04.16 at «... både evangeliene og kirkens historie (viser) at mennesker fra første stund har oppfattet fortellinger og budskap ulikt. ... Vår egen folkekirkelige, teologiske tradisjon bærer preg både av den lutherske arv og dialogen med opplysningstidens, vitenskapens og humanismens idealer. Vi bærer alle vår erfaringsbakgrunn med inn i møtet med skriften.». Den norske teologen Marius Timmann Mjaaland er i sin systematiske teologi opptatt av differensperspektivet, av «et logisk sammenbrudd i teologiens midte ... som unndrar seg en spekulativ innordning i et bestemt system, en bestemt prosess eller en bestemt metafysikk ...» Ved å ta «utgangspunkt i de ofte motsetningsfulle og tvetydige erfaringene, tekstene og fortellingene» skapes «et rom for å fortolke gudsbegrepet i lys av menneskelige betingelser og innenfor en forgjengelig og kontingent verden» (Mjaaland 2017:90f.)

Flerstemmigheten har altså i moderne protestantisk teologi en sentral funksjon²: Det er mangfoldet som «skaper et rom» for tilegnelse av gudsbegrepet, (Mjaaland 2017:90) eller, med Schleiermachers uttrykk, for troende egenaktivitet og selvstendighet.

Det finnes dermed både pedagogiske og teologiske grunner for en etterrettelig omgang med en flerstemmig virkelighet, også i kirkelig sammenheng. Kristen tro og tradisjon, kristen tro i praksis og livstolkning og livsmestring, alle tre dimensjoner i trosopplæringsplanen, er i et moderne hermeneutisk perspektiv nødvendigvis flerstemmig og dialogisk.

Hvordan er flerstemmighet ivaretatt i norske konfirmantbøker? Kateket og prest Hilde Fylling har i 2005 skrevet den første analyse av konfirmantbøker, og setter opp fem heuristiske kriterier: En god konfirmantbok - tar konfirmanten på alvor (1), - er kristussentrert (2), - henvender seg til hele mennesket (3), - hjelper konfirmanten ... å bli fortrolig med kilder for sin egen tro (4), - utfordrer til etisk refleksjon og etisk handling (5) (Fylling 2005:1-2). Plan for trosopplæring i Den norske kirke beskriver mål både for ungdomstiden (13-18 år) og - som en del av dette - for konfirmasjonstiden (Kirkerådet 2010: 21-25). Den bruker en

2 Flerstemmighet kan spores tilbake til blant annet apofatisk teologi i oldkirken, som problematiserer språkets evne til å gjøre entydige utsagn om Gud og tyr til negasjoner og paradokser som løsning for problemet. En av de første protestantiske teologene i moderne tid som understreker flerstemmighetens betydning er Friedrich Daniel Ernst Schleiermacher, som anser motsetning, veksel, og spenning mellom den enkelte stemme og helheten som en premiss for selvstendig gudstjenestedeltakelse (1850, i Herbst 1992:201). Den lutherske liturgikeren Gordon Lathrop understreker at den kristne gudstjenesten allerede i oldkirken var preget av «juxtaposition» og «unresolved tension»: man lot forskjellige stemmer lyde uten å harmonisere dem. (Lathrop 1998, 10f.). 
rekke pedagogiske begrep som «refleksjon», «dialog», «samtale», «medbestemmelse», som vanskelig kan innfris uten en viss form for flerstemmighet, og fokuset på å innøve kirkelig praksis er tonet noe ned sammenlignet med andre avsnitt i planen. Bostrøm mener at konfirmantbøkene i Dnk representerer i hovedsak «den offisielle, mer sakramentalt orienterte kristendomstype» (149), samtidig som de er «rundere av kantene» og «konsentrerer seg om temaer som 'bygger opp rundt' det mer dogmatiske» (Bostrøm 2007: 146). Innholdsmessig flerstemmighet ser altså ikke ut til å spille en fremtredende rolle i tidligere konfirmantverk. ${ }^{3}$ Gjelder dette også for de nyeste læreverk?

\section{Analysespørsmål og presentasjon aV materialet}

Ikke alle konfirmantopplegg faller under kategorien lærebøker slik som det er forstått i lærebokanalyse. I nærmere forstand gjelder det bare for konfirmantopplegg som gir en konfirmantbok med innhold i hendene til konfirmanten (Fylling 2005: 2). Et læreverk slik som de tre som er analysegjenstand her, skal imidlertid ikke bare presentere kunnskap, men gi innholdsrelatert og didaktisk veiledning til undervisere i tillegg. En kan derfor forvente at både innholdsrelaterte og didaktiske føringer vil tre enda tydeligere frem enn i en lærebok.

Analysen vil derfor ta utgangspunkt i lærerveiledningen. I tråd med Fyllings kriterium vil analysen også se på undervisningsenhetene om Jesus Kristus, der man kan forvente at sentralt teologisk læreinnhold blir turnert.

Analysen vil unders $\varnothing$ ke hvordan de tre læreverk konstruerer sin 'lærebokvariant' av den kristne tro: Hvordan begrunner læreverket autoritet? Hvilke former for innholdsrelatert og didaktisk flerstemmighet er til stede? I hvilken grad legges det til rette for flerstemmighet i konfirmantenes uttrykk og samtale?

\section{Konfirmantbibelen}

Innledende begrunner lærerveiledningen sin konsentrasjon av stoff med a beskrive en dobbel negativ horisont: Lærerveiledningen ser konfirmantene i et religiøst landskap der «flertallets utydelige (religiøse) praksis» på den ene siden, blir møtt med RLE-faget som presenterer religioner $\mathrm{i}$ «usortert form» på den andre siden. Derfor klarer ungdommene «sjelden å holde religionene fra hverandre». Velger de konfirmasjon, «ønsker de derimot å ... få ryddet opp i sine rotete forestillinger om ulike religioner». På den måten karakterisert som religiøst forvirrede ungdommer «gleder de seg til å bli forklart kristendom av en som praktiserer og kan stå inne for det som sies.» (11) Innledningen presenterer Bibelen både som en hellig bok, kilden for Guds ord, og som gjenstand for forskning. Forskningsinnsats gjennom århundrene, utbredelse som verdens mest solgte bok, og betydningen for norsk kultur og språk og Bibelens betydning

3 For en didaktisk analyse av konfirmantopplegg se Kittelsen 2010. 
som hellig bok underbygger hverandre. At Bibelen blir oppfattet og tolket forskjellig opp igjennom historien, blir tematisert senere i en nærmere innføring i bibeldidaktikk: «Det at Bibelen er i bruk og samtidig forandrer seg, gjør at vi kan snakke om Bibelen som en levende tekst» (74). I all hovedsak ser lærerveiledningen her for seg tolkninger før og nå (75), men ikke forskjellige tolkninger på samme tid. Målet med argumentet er i begge tilfeller å underbygge Bibelens autoritet, ikke å åpne opp for flere stemmer i eller om Bibelen. Bibelen er Den store fortellingen, som finner sin fortsettelse i kirkens liv, helt frem til konfirmanten, som skal skrive sin fortelling inn i denne konteksten. Gjennom dette får konfirmanten «et trygt ståsted» og «identitetsskapende fortellinger med varig verdi og bærekraft» (12f.) I bibelutgaven som gis konfirmantene i hende, blir arbeidsmaterialet til konfirmantene innrammet av Bibelens tekst. På den måten trekkes det igjen veksler på Bibelens autoritet; konfirmantbibelen står også i en tradisjon med gamle husbibler som ikke sjeldent var supplert med et kateketisk og oppbyggelig vedlegg.

Ved siden av Bibelen har Lærerveiledningen til konfirmantbibelen i hovedsak to tunge stemmer: For det første støtter man seg på Opplæringslovens (82) og KRLE-læreplanens autoritet. Faglige kilder på didaktikk og på konfirmantenes livsvirkelighet er stort sett hentet fra det skolepedagogiske fagfeltet. KRLE-fagets kategorier brukes for å forklare hva kristen tro er og ikke er: «I konfirmantundervisningen er det viktig å bruke begrep og forståelsesrammer fra konfirmantenes erfaringer fra skolen ...» (26). Mens innledningen også nevner kirken og hjemmet som «systemer» med innflytelse på ungdommers religiøse læring, er skolen den viktigste premissleverand $\emptyset$ ren i boken. Slik kommer en del apologetiske tema inn i lærerveiledningen: man skiller mellom utenfra-språk og innenfra-språk i forhold til religiøse fenomener, den kristne betydningen av Jesus avgrenses mot andre religionsstiftere osv. (44-54). Konfirmantbibelens kristendom blir med andre ord konstruert med KRLE-faget og en flerreligiøs virkelighet som referansepunkt.

Emmaus-modellen er den andre, mer didaktiske fagstemmen. Emmausmodellen er opprinnelig en katolsk bibeldidaktisk metode (Erlandsson 1999). Utgangpunkt er elevenes egen erfaring, som så i møtet med bibelteksten fremstår i et annet religiøst lys, og fører til at man går nye veier (jf. erfaringen av disiplene på vei til Emmaus beskrevet i Luk 24). Begrepet brukes imidlertid ikke bare bibeldidaktisk, men som en overordnet struktur for hele læreverket. Dette gjøres ved å tolke trosopplæringsplanens dimensjoner som skritt i Emmaus-didaktikken (s.38-39): Den første Emmaus-fasen blir likestilt med livstolkning og livsmestring, den andre fasen, møtet med bibelteksten, blir til møtet med kirkens tro og tradisjon, og den tredje fasen blir likestilt med kristen tro i praksis. Trosopplæringsplanens didaktiske sirkel blir slik omtolket til en 
ensrettet prosess. Denne overordnete strukturen blir så tilknytningspunkt for et omfattende tilfang av pedagogisk og annen fagkunnskap, og for en rekke bibeldidaktiske og andre religionsdidaktiske grep. Det didaktiske stoffet gis dessuten religiøs tyngde ved å ikle det religiøse navn: Trosopplæringsplanens forholdsvis nøkterne triade «livstolkning og livsmestring - kirkens tro og tradisjon - kristen tro i praksis» (s.15) får i konfirmantbibelens tolkning betegnelsen Emmaus-modell - et ord som har en mye mer spirituell klang. Vi hører også om Ordets skole, kontekstuell bibellesning, møtet med religionene mm. Lærerens forhold til konfirmantene blir sammenlignet med Jesu forhold til disiplene (Lærerveiledningen, 33). Didaktikken tilskrives en religiøs autoritet.

Når man går litt mer i detalj, kommer andre tilnærminger til flerstemmighet inn i bildet: Flerstemmighet mellom religionene tar en stor plass; et sammenlignende utenfra-blikk på kirken (s. 47) og diskusjon av forskjeller mellom religionene blir det tatt høyde for. Mens lærerveiledningen på den ene siden fastholder at kristendommen som tankesystem stiller et sannhetskrav (46), ser lærerveiledningen også at ungdom «beveger seg utenfor kirkene for å finne svarene» (54), og at de «nærmer seg religion gjennom erfaring» og utprøving (46). Referansepunktet består i det «hermeneutiske imperativet» (s.49), som «gjør hvert menneske ansvarlig for sine egne fortolkninger». Betoningen av det hermeneutiske imperativet kommer lærebok-idealet om drøfting av forskjellige stemmer ganske nær. Imidlertid forblir det uklart om forskjellige tolkninger relaterer til forskjellige bibeltolkninger, forskjellige kristne tradisjoner eller forskjellige religioner. Ut fra konteksten (50) tenker man på en stillingtaken for kristendommen og mot andre religioner.

Når det kommer til flerstemmighet i konfirmantenes uttrykk og samtale, pendler opplegget mellom flerstemmighet og til dels ganske drastisk ensretting (jf. karakteriseringen av konfirmantene som religiøst forvirret gjennom hjem og skole). I en mellomposisjon har vi avsnitt som det allerede siterte hermeneutiske imperativ, men også refleksjoner om bibelfortellingen som identitetsskapende rom og dens rolle for konfirmantenes identitet - her er det usikkert om fortellingen blir en del av individets identitetsskapende narrativ eller om individets identitet skal formes gjennom en fremskriving av en kristen identitet (70). På den mer flerstemmige siden finner vi henvisninger til at konfirmanter beveger seg på tvers av mangfoldige religiøse forestillinger og tradisjoner (se ovenfor), men også enkelte klart positive holdninger til flerstemmighet (100).

Appendikset i slutten av Lærerveiledningen inneholder ytterligere didaktiske og metodiske tilnærminger. Opplegget er det eneste som har et eget avsnitt om universell utforming og om undervisning for konfirmanter med funksjonsnedsettelse. Med henblikk til behandlet pedagogisk stoff kunne den godt blitt satt opp som pensum i religionspedagogisk grunnutdanning. 


\section{Konfirmantbibelen om Jesus}

Den første av læreverkets fire undervisningsenheter om Jesus Kristus: Jesus hvem var han? skal presentere Jesus som «sann Gud og sant menneske» (133, 134). Lærerveiledningen gir en oversikt over faktakunnskap: Jesu oppvekst, familieforhold, og forkynnelsen. Undervisningsenheten Jesus - hvem er han? tar opp påskehendelsen og Jesu kors og oppstandelse. WWJD (What would Jesus do) er en undervisningsenhet som presenterer Jesus som forbilde. Formelen WWJD, ofte uttrykt ved å bære et armbånd med disse bokstavene, har etablert seg som et fast uttrykk i kristen populærkultur. Konkret handler det om å ta moralsk standpunkt i en gitt situasjon ved spørsmålet: Hva ville Jesus gjort i mitt sted? Livet med Jesus handler om egen troserfaring som blir tematisert som et vennskap med Jesus. Konfirmantbibelen formulerer: «å ha en venn som også er Gud.» (Konfirmantbibelen: Brukerveiledning s.40)

Selv om tekstrelaterte metoder dominerer, åpner opplegget metodisk et ganske stort rom for forskjellige tilnærminger til undervisningens tema: Konfirmantene blir bedt om å drøfte Jesusbilder på forskjellige måter, og en rekke relevante bibelske tekster skal i kreativt bibelarbeid omsettes til rap, intervju, tabloidreportasje eller dagbok-tekst. Det brukes liturgiske elementer som påskevandring, og liturgiske avslutninger til undervisningstimen, til dels med små oppgaver, og man beskjeftiger seg med ungdoms- og popkulturelle elementer som WWJD-armbånd eller musikkvideoen ,Judas' fra Lady Gaga. Man leker; man er med på å konstruere Peters troshistorie ut fra en sammenstilling av nytestamentlige tekster, man hører konfirmantlærerens troshistorie og drøfter sin egen. Imidlertid legger spørsmålene og oppgavene som stilles, stort sett ikke opp til synliggjøring av eget standpunkt, men til gjengivelse av det som er gitt i de bibelske historiene. Når det gjelder troshistorie, brukes kun Peters historie, hvis dramatikk med svik, anger og tilgivelse har gjenklang i en pietistisk forståelse av frelse. Fortellinger om eksempelvis Thomas Tvileren, Maria, Maria Magdalena, Zebedeus-sønnene, som ville presentert et mangfold av trosfortellinger, blir ikke brukt. Undervisningsenheten WWJD om Jesus som forbilde bruker bibelsteder som er sentrale for forståelsen av den neste i Det nye testamentet - Matt 25, 31-40 og Lukas 10, 30-32, samt et utdrag fra bergprekenen. Bibeltekstutvalget kutter imidlertid rammefortellingen som knytter tekstutsagnene til en overordnet teologisk og mer prinsipiell ramme; sammenholdt med bibeltekstenes horisont fremstår enhetens moralske problemstillinger (snike på bussen, jukse på en prøve osv.) som hverdagslige og private. Lærerveiledningen sammenfatter: «vi skal oppføre oss ordentlig mot alle. Vi kan ødelegge en dag for noen, eller gjøre en dag god.» (160). Mens lærerveiledningen presenterer historiske fakta om Jesus for de som underviser, blir kunnskap om Jesus for konfirmantene med en gang stilt under innordning som fortegn: Fortellingen om de 
tre vise menn og stjernen (Matt 2) underbygger Jesusbarnets guddommelighet, og fortellingen går umiddelbart over i andre trosartikkel i den nikenske trosbekjennelsen (Konfirmantbibelen, Brukerveiledning s.25). Undervisningsenheten WWJD understreker at å velge rett kan være vanskelig: «Godt å kunne forankre egne valg i noe som er større enn oss selv ...» (160) Temasidene i konfirmantbibelen er enda tydeligere på det punktet: «Jesus er dessuten Guds egen sønn og hans makt er større enn din. Derfor skal bokstavene WWJD først og fremst minne deg på at du er kalt til å gjøre noe.» (39). Undervisningsenheten om påske kombinerer liturgiske grep, en drøfting av 1Kor 15 med sine gammeltestamentlige profetier og vitneutsagn om og tidlige tolkninger av Jesu oppstandelse, og gruppearbeid om 'Judas' - en musikkvideo fra Lady Gaga som inneholder mange referanser til kristne symboler knyttet til påske. Enhetene konkretiserer autoriteten og betydningen i det som blir sagt på forhånd: Jesus ER Gud, Påske ER viktig, og her skal du bli del av noe større.

\section{Nøkler til livet}

Forfatterne til Nøkler til livet avgrenser seg fra katekismepreget konfirmantundervisning: «Ungdom er mest interessert i livsnære spørsmål. Da er det krevende ... å skulle motivere dem til å lære om kristen dogmatikk.» (11) Hensikten er ikke å tilsidesette dogmatiske temaer, men å «relatere samlingene tydeligere til deltakernes liv» (12). Ungdommens egen hverdag er sentralt: «Ungdommene kjenner best hva de kan bruke i egen livstolkning.» (25). Opplegget tar to grep for å fokusere på dette: Stoffet blir ordnet under to hovedoverskrifter, «vennskap» og «meningen med livet». Disse to overskriftene - også omtalt som to moduler som kan brukes sammen eller parallelt - gjenspeiler temaer med høy popularitet blant konfirmantene i konfirmantundersøkelsen 2007/2008 (Høeg/ Krupka 2010: 180) og er valgt av nettopp denne grunn. Det andre grepet er å avstå fra dogmatisk stoff til fordel for et fokus på ritualer, fortellinger og bibeltekster, kirkerommet og ungdomsrelaterte tema (16-17). Disse skal kunne fungere som «redskaper til bruk i eget liv» (17). På s. 26 gjør Nøkler til livet rede for hvilke mulige tema i konfirmantundervisningen som er valgt bort: «det som overlapper med skolens religionsundervisning» og «abstrakt og analytisk kunnskap». Tradisjonell dannelsesverdi som et utvalgskriterium for undervisningsstoff blir avvist: «Dersom 'Deg være ære' ikke hjelper dagens ungdom til livstolkning, er det ikke sikkert at den bør være en sentral salme i fremtidens kirke.» (26). Et første øyekast på innholdsfortegnelsen bekrefter påstanden: Det er ikke uten videre mulig å se ut fra overskriftene hvilke delemner som omhandler Vår Far, De ti bud, nattverd eller andre katekismetema.

Nøkler til livet går langt i å understreke betydningen av deltakernes egen refleksjon, stillingtaken og kunnskaping: «Pensum er det deltakerne bringer 
inn. » (21) Også oppleggets forhold til kirkelig tradisjon går via deltakerne (s.19): «... deltakerne selv skal kunne finne såkorn som vokser i eget jordsmonn av levd liv». Opplegget understreker betydningen av livstolkning og religiøs læring som skjer på andre læringsarenaer og mellom forskjellige av disse (22). Nøkler til livet gjør i liten grad rede for eller bruker eksplisitte kilder: Opplegget $\emptyset$ nsker mindre lære, analyse, historisk teologi, kirkehistorie, tradisjonelle salmer, og mer bibelfortellinger, ritualer, bilder og diakonale praksiser, bønn, anvendelse $\mathrm{i}$ hverdagen, egen livs- og troshistorie (s.26).

Mens opplegget er tydelig om sin teoretiske pedagogiske begrunnelse, er det lett å se at det er ungdomsgruppens og ungdomsmiljøenes religiøsitet som er den tilsiktede formen av kristendom: Oppleggets lærebok-religion er den trygge, meningsfulle, sosiale, individualiserte og religiøse samtalen som ser ut til å prege kristne ungdomsgrupper. (Høeg 2012: 208-213, Krupka 2012: 224226) Samtale i grupper skårer forøvrig høyt i konfirmantundervisningen blant norske konfirmanter i 2007/8 (Høeg/Krupka 2010:181); opplegget tar nok pulsen på kristent ungdomsarbeid på dette punkt. I motsetning til det som synes å være mest vanlig (Krupka 2012:229), satser opplegget ikke på den voksnes rolle som forbilde og tradisjonsbærer, men på ungdommenes selvstendighet. Et eget avsnitt i innledningen drøfter former for medvirkning og medbestemmelse. (27f.)

Innledingenåpner med ordene «N $ø$ kler til livet er inspirert av de sisteårs forskning på læring i kirken ...» (11) og ønsker å skape «nye muligheter» gjennom «nye metoder». (12) Opplegget drar veksler på egen og andres forskning på konfirmanter og ungdomsarbeid. Teksten er ispedd med uthevede sitater fra nyeste religionspedagogiske forskning på læring i kirken ved Geir Afdal (2013) og Elisabeth Tveito Johnsen (2014), og er nøye med å legge et pedagogisk fundament i denne tradisjonen. Dessuten er integrasjonen med KFUK-KFUM noe en spiller på flere steder, for å underbygge egen faglig autoritet.

Nøkler til livet avgrenser seg fra skolen og dens pedagogikk som anses som ikke forenlig med livsrelevant læring: «Når skole kommuniseres til ungdom, skaper man antakelser om ... at man skal lære noe som ikke nødvendigvis er relevant for eget liv, og at man skal vurderes. « (18) Kirkelig praksis, isolert sett, står under et lignende forbehold: «Dersom å være kirke kun handler om å bli deltakere i menighetens arrangementer og aktiviteter, risikerer konfirmantog ungdomsarbeidet å miste kontakt med ungdommens hverdag og virkelighet. « (22) Opplegget skal derimot skape rom til «forhandling om religion og livstolkning» på tvers av arenaer (22); lederrollen i dette rommet handler om å skape «likeverd i tolkningssituasjonen» (19): Lederens egen og deltakernes forskjellige stemmer skal være så likestilt som mulig for å muliggjøre «reell meningsskaping knyttet til livsnære spørsmål.» (19). 
Nøkler til livet fremstår med dette som individ-orientert, men ikke som spesielt flerstemmig: Ungdommene er utfordret til å drøfte sine egne livsspørsmål, uten at forskjellige tradisjoner eller flere syn blir introdusert som tema. Mens deltakernes stemmer og stemmenes likeverd inngår som en didaktisk premiss i opplegget, har Nøkler til livet ikke noe utpreget forhold til universal utforming. Forskjellige læringsformer og læringsmåter drøftes i liten grad. Praksis er i stor grad oppfattet som en samtalepraksis; satt på spissen, er opplegget mer opptatt av «å jobbe sammen med ungdommene med å velge ut (salmer)» (26) enn å synge salmer.

\section{Nøkler til livet om Jesus}

På nettsiden har Nøkler til livet en oversikt over deres undervisningsenheter og sammenhengen med tradisjonelt katekismestoff. Her listes det opp ikke mindre enn 13 delemner som har med andre trosartikkel å gjøre; de fleste hører til emnet 'Meningen med livet'. Særskilt relevant for temaet Jesus Kristus er de følgende:

Jesus som venn er tittelen på første undervisningsenhet i vennskapsemnet. Her presenteres et ikon fra 700-tallet som viser martyren St. Menas og Kristus, med Kristi arm om St. Menas skulder. Verden snudd på hodet fremstiller Jesu budskap som 'en revolusjon'. Jesusbilder tar utgangspunkt i de såkalte Jeg-erordene fra Johannesevangeliet. Disse enhetene inneholder lite saksinformasjon, med unntak av en online-undervisningsenhet som heter Hvorfor døde Jesus på korset.

Drøftingsspørsmålene er ganske nær en ungdommelig livsverden og tenkemåte, for eksempel: Hvem er det kult å henge med? som inngangsspørsmål til Jesu fellesskap med tollere (Matt 9, 11-13), Hvem blir sett opp til på skolen? som inngangsspørsmål til teksten om barna som de største (Mark 9, 33-37). Ved at mange av spørsmålene er mer eller mindre fiktive, er det imidlertid få referanser som peker utover fortellingsrommet: Inngangsspørsmålet til fortellingen om Jesu fødsel er for eksempel: Hvordan bør en prins bli tatt imot når han blir født?, for så å utarbeide forskjellene til historien om Jesu fødsel. Jesus tilkommer autoritet som en slags antihelt i en dialektikk med både prinser, kjendiser og suksessfulle personer på den ene siden, og de avmektige, upopulære og svake på den andre. Rommet som åpnes for konfirmantene å plassere seg i, er som følge av dette ganske stort. Imidlertid inviterer spørsmålene ikke til debatt at det er riktig å gjøre slik som Jesus, og at det er rimelig entydig hva det går ut på, blir forutsatt. Enheten ,Jesusbilder' konsentrerer seg om symbolene tre, brød, lys, gjeter, port, som utforskes og videreutvikles med selvskapte symboler. Spørsmålene som stilles, er i hovedsak forståelsesspørsmål som utforsker klangbunnen i metaforene: At Jesus er noe livgivende for oss som kan uttrykkes i mektige symboler, blir forutsatt. Mye av initiativet overlates imidlertid til 
ungdommen, og den kreative sluttdelen der ungdommene selv velger symboler, åpner opp for å velge forskjellige posisjoner i forhold til stoffet.

Undervisningsenheten «Hvorfor døde Jesus på korset» går lengst i å åpne opp et flerstemmig tolknings- og refleksjonsrom. Påske fremstilles som en opplevelse som blir tolket i etterkant, og som fører til flere forskjellige tolkninger. Konfirmantene blir invitert til å drøfte disse tolkninger og diskutere deres mulige betydning. Imidlertid blir ikke de nytestamentlige tolkningene drøftet opp mot historisk kunnskap om hendelsen; man inviterer deltakerne istedenfor «inn i det samme rommet som disiplene er i». Konfirmantfellesskapet, og ungdommens samtalerom, blir på den måten forstått som en aktualisering av det første kristne fellesskapet. Påske som kirkelig høytid med alle sine teologiske og kulturelle referanser er med på å gi teologisk autoritet. Men autoritet blir også delegert til ungdommene gjennom at de kan sette seg i disiplenes og teologenes sted - de blir invitert til å prøve seg ut i etablerte religiøse roller.

Den første av de nevnte undervisningsenheter markerer forskjellen mellom Nøkler til livet og de andre to opplegg i et nøtteskall: Den begynner med en samtale om ikonet og går videre til å belyse temaet vennskap med utdrag fra Ordspråkene i Det gamle testamentet. Enheten formulerer også en lekse: Å sette opp ikonet hjemme og av og til fundere over hva det vil si om vennskap, om tro og hvilken personlig betydning det kan fă. Presentasjonen av stoff er mindre spisset til et budskap enn hos de andre oppleggene, og det didaktiske rommet gir konfirmantene mer valg hvor de vil posisjonere seg i forhold til tema. Likevel har man en noe lukket referanseramme der en del av svarene allerede er gitt i forveien. At man avviser formidling av faktakunnskap og undervisningsstoff, kan bidra til at referanserommet for samtalen blir noe svevende.

\section{Delta}

Lærerveiledningen til Delta er kortere enn veiledningen til de to andre læreverkene; den refererer mindre til pedagogisk eller teologisk fagkunnskap og er på noen punkter nokså rask i sine konklusjoner. Undervisningsenhetene i Delta er derimot veldig klart strukturert og ferdig utarbeidet: Delta er det eneste av oppleggene som er så strukturert at man i en nødsituasjon kunne klart en konfirmanttime uten videre forberedelse av den. Det kan spørres om forfatterne kanskje ikke helt har lagt sin fulle faglige tyngde i veiledningen. En analyse gjør derfor mindre rede for enhetenes implisitte didaktikk og teologi, men belyser en del problemstillinger knyttet til praksislæring i konfirmantundervisning som med fordel kan drøftes også med henblikk til de to andre konfirmantopplegg.

Delta understreker sterkest betydningen av menighetens praksis for konfirmantundervisningen. Opplegget presenterer konfirmantene som ikke opptatt av teologiske spørsmål, men av «hva de kan bruke og hva de kan gjøre» (5) De 
trenger derfor ikke teologisk innsikt, men å møte «praksisene vi har i kirken» (5). Imidlertid understrekes det også betydningen av teologisk innsikt, når konfirmantene skal både «erfare seg selv som en integrert deltaker i menighetens fellesskap og praksiser», og de skal lære «kjerneinnhold i kristen tro» (s.6). Deltas lærerveiledning presenterer ikke troens innhold og kirkens praksis på noen måte som flerstemmig. Det nevnes heller ikke noen kilder utover en henvisning til trosopplæringsplanen (s.6).

Den kirkelige praksis som Delta presenterer i innledningen, er i hovedsak en praksis som skapes for konfirmantundervisningen, konkretisert til «samtale i hjemmet, leir, faddertjeneste og deltakelse i menighetens praksiser»(s.4) De første tre praksiser finnes ikke uten videre i den kirkelige virkeligheten: Samtale i hjemmet, også kalt Delta hjemme, er en ritualisert samtale mellom foreldre og konfirmanter om tema i konfirmantåret med en liturgisk åpning og avslutning. Hensikten er «å stimulere familien til å snakke åpent om tro og tvil sammen» (9). Det er vanskelig å se for seg at denne form for familieandakt med ungdommer finnes utenom noen svært begrensede kristne miljøer, og Delta gir utførlige tips til hvordan man kan innføre denne praksis ved å fremsnakke den i konfirmantforeldrem $\emptyset$ ter og løfte frem familier som faktisk gjør det, som gode eksempler (s.10).

Faddertjenesten ser for seg å involvere eldre ungdommer, konfirmantforeldre og -faddere, og andre personer i menigheten til «å be jevnt og trutt for navngitte konfirmanter» (12). Disse navngitte konfirmanter skal presentere seg for vedkommende gjennom et skjema med personopplysninger ( «slik at konfirmantlæreren og bønnefadderen raskere kan bli kjent med hverandre», s.12). Faddertjenester finnes i noen menigheter, men som Delta selv forklarer og gir veiledning til, er konfirmantfaddertjeneste også en praksis som i stor grad trenger å bli skapt fra de som ønsker å satse på dette.

Konfirmantleir er forholdsvis utbredt i Den norske kirke. Ca. $59 \%$ av alle konfirmanter deltar i konfirmantleir på tre dager eller lengre (Niemelä/Ilg 2015: 108), men slett ikke alle konfirmanter opplever leir. Delta omhandler leir forholdsvis kort, men understreker betydningen av en rekke spesifikke aktiviteter: bønnevandringer, lystenning, vitnesbyrd, skriftemål, bordvers, korssamlinger, nattverd, sangkvelder, bibellesning, andakt og bibeltimer (13). Disse aktiviteter hører imidlertid bare delvis til standardrepertoaret for trospraksiser i Den norske kirke. Noen av forslagene for konfirmantinvolvering i menighetens praksis virker i grunn lite gjennomtenkt (for eksempel grillfest for uteliggere). Praksisen som konfirmantene skal delta i, skapes med andre ord gjennom konfirmantundervisningen.

Innledningen til Delta har sterkt fokus på religiøse ritualer og fellesskapsritualer. Ritualene som foreslås, forutsetter til dels både en stor grad av tillit og 
utlevering, og de er innholdsmessig tydelig og spisset. Sånn sett gir de lite frihet for personlig uttrykk og lite rom for personlig interpretasjon. Spesielt tydelig blir dette i avsnittet om trygt rom. 'Trygge rom' (Safe Spaces) er et begrep og en metodikk som er utviklet for å skape rom for å dele og bearbeide særdeles sårbare erfaringer, for eksempel erfaringer av annerledeshet (Roux 2012) eller overgrep (Engedal m.fl. 2013, jf. Lærerveiledning til Konfirmantbibelen s.7). I Delta er hensikten med trygt rom «at ikke tankene vandrer til hverdagens bekymringer, eller at følelsesmessig eller kroppslig uro tar all oppmerksomheten » (7). Det handler med andre ord om klasseledelse. Sammenlignet med klasseledelse i en vanlig undervisningstime i skolen, fremstår anbefalingene som ritualisert, alvorspreget og sakralisert: en ryddig og innbydende atmosfære i rommet, et bord med hvit duk, tente lys og en oppslått Bibel, sakral musikk når konfirmantene kommer inn, navnelapper på stolene, en ritualisert velkomsthilsen fra konfirmantlæreren, muligheten til å si ifra om noe ikke er som det skal, samt åpen rømningsvei, trygge og helst skriftlige regler, konsekvente sanksjoner, samt regler for hva som skal være privat og hva som er greit å dele. Man må spørre om et slikt repertoar kanskje har mer disiplinerende enn tillitsbyggende karakter i konfirmantundervisningen og bør forståes kritisk som maktpraksiser som skal underbygge innholdets autoritet.

\section{Delta om Jesus}

Delta omhandler Jesus Kristus spesifikt $i$ to undervisningsenheter. Undervisningsenheten Jesus døde og sto opp - hvorfor? stiller Jesu korsfestelse i midtpunktet. Undervisningsenheten Hva ville Jesus? snakker på den ene siden om etterfølgelse og disippelskap, om Jesus som veien, sannheten og livet, men på den andre siden om den mer etisk/moralske siden av Jesu budskap.

Den didaktiske rammen plasserer Jesu betydning i en kontekst preget av personlig tro og fromhetspraksis. Opplegget bruker i liten grad eksterne referanser for å begrunne autoritet (annet enn for eksempel konfirmantbibelen); Delta dveler ved det eksepsjonelle i at Jesus ofrer seg selv som en kjærlighetshandling. Korset blir utførlig behandlet som et symbol i spenningen mellom torturredskap og kjærlighetsuttrykk. Undervisere blir oppfordret til å dvele ved grusomhetene ved å gjenfortelle «mer detaljert hendelsene fra langfredag til påskedag: dommen, piskingen, den ydmyke gangen opp til Golgata, Jesu siste ord på korset, tidspunktet hvor Jesus dør, gravleggingen, kvinnene ved den tomme graven, » (s.54) Spørsmålene som stilles, er i all hovedsak forståelsesspørsmål; selv om lærerforedraget om korsfestelsen nevner forskjellige tolkninger og åpner for enda flere, forutsetter фvrig materiale at tolkningen som kjærlighetshandling blir akseptert: Dette vises for eksempel når konfirmantene blir utfordret til å skrive «en takkebønn for Guds kjærlighet til deg og alle mennesker. Be om at 
hans kjærlighet skal få prege ditt liv og bli til glede for mennesker du er sammen med.» (veiledning s.55). Referanser til konfirmantenes livsverden derimot er få og noe lettvektig, for eksempel når Jesu d $ø$ d blir parallellisert med ting man gjør for å vise sin forelskelse (f.eks. lage ein personleg og pinleg kjærleikssong, for så å syngje for henne eller han i skulegarden (logg s.26).

Imidlertid kommer det en saklig åpenhet inn i undervisningsenhetene når undervisningsstoff blir fremlagt i lærerforedrag: Undervisningen gjør for eksempel rede for en historisk forståelse av Jesu død som religiøs provokatør og trekker opp klassisk, objektiv og subjektiv forsoningslære som tolkninger av Jesu korsd $\emptyset$ d. Under overskriften 'mysterium' holdes spørsmålet om hvilken tolkning som er rett, åpen: «Bestem selv hvor mye du vil gjøre ut av dette.» (veiledning s.55). Oppstandelsen blir i Konflogg uttrykkelig betegnet som et trosutsagn. Undervisningsenheten om Jesus som forbilde er preget av ganske mye stoff fra forskjellige kilder og med dette av en viss flerstemmighet; enheten nevner eksplisitt at «mange har ulike innfallsvinkler når de skal finne kjernen $\mathrm{i}$ budskapet» (73). St $ø$ rsteparten av spørsmålene som stilles, er imidlertid fokusert på tekstforståelse, og svarene er gitt. De mer kreative oppgavestillinger og en og annen spørsmålsstilling er mer åpen og tillater konfirmantene å plassere seg forholdsvis fritt i forhold til det presenterte materialet.

\section{SAMMENFATTENDE DRøFting}

Fra analysen kan det sammenfattes tre mulige forankringspunkter for flerstemmighet i en konfirmantbok:

Flerstemmighet som er forankret i undervisningens materiale gjennom flere faglige perspektiv eller faglige kilder. Den typen flerstemmighet er i liten grad å gjenfinne i de tre undervisningsoppleggene. Konfirmantbibelen avviser den gjennom sitt apologetiske fokus på entydighet og autoritet. Nøkler til livet legger opp til en individualisert drøfting og stillingtaken i konfirmantundervisningen, men dette er i liten grad formidlet gjennom faglige perspektiv eller kilder. I Delta er flerstemmighet ikke tematisert i lærerveiledningen, men forekommer i tilknytning til presentasjon av undervisningsstoff. Kanskje den mer skolske tilnærmingen medfører en viss etterrettelighet med henblikk til at teologi er flerstemmig.

Religiøs flerstemmighet av konfirmantenes livsverden og egen praksis. Konfirmantbibelens lærerveiledning har relasjoner til skolens behandling av kristendom og til skolens rasjonalitet og drøfter pedagogisk psykologi, men fokuset er i liten grad å finne igjen i de unders $ø$ kte undervisningsenhetene. Konfirmantenes religiøse flerstemmige hverdag blir dessuten tolket som en mangel. Nøkler til livet er mest poengtert opptatt av å være i kontakt med ungdommenes livsverden og hverdag i innledningen. Den er også mest åpen 
for individuell stillingtaken og debatt. Men det finnes generelt lite eller ingen refleksjon om forskjeller i elevenes religiøse eller kirkelige bakgrunn i disse tre konfirmantlæreverkene; To av tre tar ikke en gang opp pålagte hensyn til konfirmanter med nedsatt funksjonsevne; det samme gjelder Plan for samisk trosopplæring som virker nokså ukjent for alle.

Mens disse to former for flerstemmighet er i tråd med kriteriene utviklet innen lærebokanalyse, synliggjør gjennomgangen et annet viktig aspekt ved flerstemmighet i undervisningen: Flerstemmighet som inviterer til selvstendig stillingtaken og trosuttrykk, didaktisk forankret i åpne spørsmål og mangfoldige arbeidsformer. Konfirmantbibelen er det opplegget som viser mest metodisk mangfold og åpenhet for kreative uttrykk i de unders $\emptyset$ kte undervisningsenhetene. Imidlertid er det produksjon av tekst og gruppesamtale i en eller annen form som råder grunnen i alle tre læreverk, og andre uttrykksformer er mer unntaket enn regelen. I det unders $\varnothing$ kte materialet legger ingen av oppleggene opp til virkelig kontroverse diskusjoner om religiøse og vanskelige tema; spørsmål som stilles, holder seg innenfor en nokså lukket referanseramme.

Når flerstemmighet av kilder og av faglige syn i liten grad blir presentert for konfirmantene i disse tre læreverk, og når det er lite rom for kontrovers debatt gjør det noe? Er ikke det greit å presentere troen på Jesus for konfirmantene med innlevelse og autoritet? Analysen viser et fellestrekk der de tre læreverk muligens betaler prisen for manglende hensyn til kritisk faglighet: De er preget av et visst realitetstap.

Det unders $\emptyset$ kte materialet fra alle tre undervisningsverk inviterer konfirmantene inn $i$ en narrativ verden som er befolket av bibelske personer som disippelen Peter, av bibelske symboler som Betlehemsstjernen, av teologiske læresetninger som læren om Kristi to naturer og en rekke rituelle handlinger som for eksempel fotvaskelse. Den presenterte narrative verden er et harmonisk univers og er det samme for alle som beveger seg i den; kun enkelte ganger forekommer det henvisninger til forskjellige tolkninger eller til at ting kan være vanskelig å forstå eller oppleves forskjellig. Referansene til nåtiden i denne narrative verden er ofte kulturuttrykk, altså fiksjon; i Konfirmantbibelen for eksempel blir autoriteten av dette universet underbygget med referanser til populærkultur. Referanser til konfirmantenes livsverden er få, etiske spørsmål som blir drøftet, kan være nokså harmløse og ufarlige. Tydeligst er dette kanskje i Delta og dens innledende filmsnutter med komisk dukketeater som minner om amerikanske sitcoms fra 90-tallet, befolket med muntre, sorgløse og litt naive konfirmanter, snille og litt avleggse gamle prester og kjærlige og bekymrede foreldre med klassisk dobbeltmoral. Gyldigheten av trosuniverset blir i alle tre opplegg forutsatt; ingen av oppleggene tar virkelig høyde for at ungdom tviler og har grunnleggende spørsmål. Teologisk sett har dette en pris: Ved å sette det narrative universets 
sannhet utenfor enhver tvil forsvinner rommet til å reflektere over tro i møte med «de ofte motsetningsfulle og tvetydige erfaringene, tekstene og fortellingene» (Mjaaland 2017:90f.).

Oppleggene har noe forskjellige referansepunkter for å konstruere sin lærebok-variant av kristendom. Men begrepet kristen praksis spiller en viktig rolle i alle tre konfirmantverk. Kristen praksis forstås i hovedsak som små religi$\emptyset$ se og rituelle handlinger, sterkt knyttet til konfirmantenes samvær og diskurs. De er med på å prege lærebok-religionen som konfirmantene blir møtt med. Selv om de har gjenklang og inspirasjon fra retreatbevegelsens praksisformer og praksiser i pietistiske eller karismatiske kretser, kan det spørres i hvilken grad de representerer det vanlige rituelle eller liturgiske repertoaret i Den norske kirke. At konfirmantene gjennom dem blir møtt på sin egen nokså forskjellige religiøse praksis, er tvilsomt. Derimot har de en viktig funksjon for trosuniverset som konfirmantene blir introdusert for, der de fungerer som en slags universal utforming eller rituell fundamentering av dets autoritet. De har også en fellesskapsbyggende og til dels disiplinerende funksjon. Enkelte ganger forutsetter praksisene en grad av intimitet og utlevering som ikke helt respekterer konfirmantenes grenser.

Alle tre undervisningsverk er gjennom dette til en viss grad preget av en dynamikk, som egentlig er godt beskrevet i Emmausmodellen. Veien fører fra konfirmantenes liv og dens tolkning, via et narrativt møte med kristen tro og tradisjon, inn i en ritualisert praksisverden knyttet til konfirmantåret - men ikke tilbake. Man kan spørre om ikke konfirmantene blir invitert til å bevege seg i denne verden som i et dataspill: man kan utforske noen symboler her, følge en fortelling og bli kjent med noen karakterer der, utforske et repertoar av utsagn rundt en person eller en hendelse et annet sted, men referanserammen er lukket, og utbyttet for livstolkning og livsmestring begrenset. Nesten halvparten av konfirmantene synes i 2013 at konfirmantundervisningen har lite å gjøre med deres hverdag (44\% i 2013, $38 \%$ i 2008. Schweitzer m.fl. 2010: 315, Schweitzer m.fl. 2015: 377); kanskje grunnen ligger i den beskrevne dynamikken.

Man kan forstå de tre konfirmantopplegg som tre posisjoner på et kontinuum mellom «skolsk» og ungdomsarbeidspreget konfirmantopplegg. Delta er da det opplegget som er mest skolsk, med en tydelig dose med lærerforedrag og stoff. Nøkler til livet er det mest ungdomsarbeidspregede opplegget. I et slikt perspektiv blir det synlig at det har sin pris å forlate skolens referanseramme: En etterrettelig og konsentrert omgang med et tema eller et innhold er ikke så enkelt å få til uten en tavle, en stol, et bord og en fagbok eller to.

Man kan også argumentere at en viss løsrivning fra den reale verden kjennetegner mange former for ungdomsarbeid, at det er en nødvendighet for ungdommer å utvikle seg, teste grenser og eksperimentere med roller og 
forestillinger i en pedagogisk provins eller et simulatorrom. I god ungdomsarbeids-tradisjon forstår Nøkler til livet ungdomsmiljøet som en fornyingsagent i forhold til kristen tradisjon, med mye selvbestemmelse og en relativ uavhengighet fra voksenverdenen. Men også her er dette en narrativ verden befolket av prinser, disipler, skomakere, gjetere og vintrær; i hvilken grad konfirmanter innskriver sine erfaringer fra livet utenfor denne verdenen inn i den, er ikke tema for didaktisk refleksjon.

Betyr denne kritiske analysen at konfirmantlærere helst bør vente med a kjøpe konfirmantlæreverk til noe annet kommer på markedet? Nei, for all del! Alle tre læreverk har sine styrker. Men følgende tre spørsmål kan være nyttige når man forbereder konfirmanttimer med dem:

Hvilke faglige og virkelighetsnære problemstillinger kan erstatte tidsl $\varnothing$ st og narrativt innhold i undervisningsenheten? Her hjelper det å være oppdatert på aktuelle etiske og religiøse tema i samfunnet. Eller, når man først bruker en musikkvideo med Lady Gaga som materiale, kanskje det er like interessant å se på hvilke saker hun engasjerer seg for, og hvor kirken står i disse saker?

Hvordan skal undervisningen tilpasses didaktisk og diakonalt til akkurat denne konfirmantgruppen? Er alle like glade i å snakke og diskutere, eller er det noen som har det bedre med andre aktiviseringsformer? Er det konfirmanter i gruppen som lever alt annet enn et bekymringsfritt tenåringsliv i forstaden og hvilke spørsmålsstillinger, arbeidsformer og kristne praksiser vil møte disse?

Hva er de vanskelige religiøse eller teologiske spørsmål knyttet til undervisningsenheten, de som går på tro og tvil? For eksempel: Hva vet vi, og hva vet vi ikke, historisk fundert, om Jesus? Må man ta oppstandelsen bokstavelig, og hva betyr det egentlig? Hvordan får man Gud og skapelsen, og naturvitenskapen og en sekulær hverdag til å henge sammen? De fleste undervisningstema har slike vanskelige spørsmål, og dersom konfirmantlæreren utfordrer dem istedenfor å legge lokk på dem, kommer debattene, spørsmålene og læringsutbyttet nærmere på virkeligheten konfirmantene lever i.

\section{LitTERATUR}

Afdal, Geir, 2013. Religion som bevegelse. Lœring, kunnskap og mediering. Oslo: Universitetsforlaget.

Andreassen, Bengt-Ove, 2014. Theoretical Perspectives on Textbooks/Textbooks in Religious Studies Research. S. 1-15 i: Andreassen, Bengt-Ove, Lewis, James R.: Textbook Gods. Genre, Text and Teaching Religious Studies. Sheffield/Bristol: Equinox. Bostrøm, Edgar, 2007. Konfirmantmateriale i norske kirkesamfunn. En analyse av innhold, konfesjonalitet og overordnet pedagogisk utforming. Masteravhandling. Det teologiske Menighetsfakultet. 
Engedal. Leif Gunnar, Persson, B. Lennart, Torp, Elisabeth (red.), 2013. Trygge rom. Trosopplcering i møte med sårbare og overgrepsutsatte barn og unge. Oslo: Verbum.

Erlandsson, Ulrika, 1999. «Emmaus-modellen». S.15-18 i: Metodboken Bibel 2000. Stockholm: Verbum.

Fylling, Hilde, 2005. Valg av konfirmantbok - valg av konfirmasjonsprofil. (upublisert, brukt i emnekompendier på MF).

Høeg, Ida Marie, 2012. Fellesskap og kulturell tilhørighet. S. 199-217 i: Prismet 4-2012. Høeg, Ida Marie, Krupka, Bernd, 2010: Confirmation Work in Norway. S. 162-183 i: Schweitzer/Ilg/Simojoki: Confirmation work in Europe.

Innanen, Tapani, Krupka, Bernd, 2010. Planning and Teaching in Confirmation work. S. 222-234 i: Schweitzer/Ilg/Simojoki: Confirmation work in Europe.

Johnsen, Elisabeth Tveito, 2014. Religiøs loering i sosiale praksiser. En etnografisk studie av mediering, identifisering og forhandlingsprosesser i Den norske kirkes trosopplaring. $\mathrm{PhD}$-avhandling. Oslo: Det teologiske fakultet, Universitetet i Oslo.

KFUK-KFUM ved Jan Christian Kjelland 2015. Nøkler til livet. Nye metoder for læering $i$ kirken. KFUK-KFUM.

Kirkerådet, 2010. Gud gir - vi deler. Plan for trosopplæering i Den norske kirke. Oslo.

Kittelsen, Line, 2010. Se og bli sett. Hvilke syn på læering finnes $i$ konfirmantbøkene

Brukerveiledning og Konfirmantbibelen? Masteravhandling. Det teologiske Menighetsfakultet.

Konfirmantbibelen. Bibelselskapet 2002, 2016.

Leganger-Krogstad, Heid, Langkaas, Randi, Engen, Nina, Nygård, Inger Helen, Skeie, Sindre, 2015. Konfirmantbibelen Lærerveiledning. Oslo: Verbum

Krupka, Bernd, 2012. Tro som sosialt eksperiment. S. 219-232 i: Prismet 4-2012.

Lathrop, Gordon, 1998. Holy Things. A Liturgical Theology. Minneapolis: Fortress Press Midtsund, Brage Molteberg, 2015. Konflogg. Konfirmantbok. Delta konfirmant. Oslo: IKO.

Midtsund, Brage Molteberg, Liodden, Runar Johannessen m.fl. 2016. Delta Larerveiledning. Oslo: IKO (2. opplag).

Mjaaland, Marius Timmann, 2017. Systematisk teologi. Oslo: Verbum.

Morgan, Katalin, Henning, Elizabeth, 2013. Designing a Tool for History Textbook Analysis. Forum: Qualitative Social Research Vol. 14, No.1, Art.7.

Niemelä, Kati, Ilg, Wolfgang, 2015. From Classrooms to Camps? Effects of Different Physical Learning Spaces and Teaching Methods in Confirmation Work. S.106116 I: Schweitzer/Niemelä/Schlag/Simojoki: Youth, Religion and Confirmation work in Europe.

Pingel, Falk, 2010. UNESCO Guidebook on Textbook Research and Textbook Revision. Paris/ Braunschweig 2. utg. 2010.

Roux, Cornelia (red.), 2012. Safe Spaces. Human Rights Education in Diverse Contexts. Rotterdam: Sense. 
Schleiermacher, Friedrich Daniel Ernst 1850. Die Praktische Theologie nach den Grundsätzen der ev. Kirche im Zusammenhange dargestellt, utdrag i: Herbst, Wolfgang, (ed.) 1992. Evangelischer Gottesdienst. Quellen zu seiner Geschichte. Göttingen: Vandenhoek\&Ruprecht.

Schweitzer, Friedrich, Ilg, Wolfgang, Simojoki, Henrik (red.), 2010. Confirmation Work in Europe. Empirical Results, Experiences and Challenges. A Comparative Study in Seven Countries. Gütersloh, München: Gütersloher Verlagshaus. Konfirmandenarbeit erforschen und gestalten

Schweitzer, Friedrich, Niemelä, Kati, Schlag, Thomas, Simojoki, Henrik (red.), 2015. Youth, Religion and Confirmation Work in Europe. The Second Study. Gütersloh, München: Gütersloher Verlagshaus. Konfirmandenarbeit erforschen und gestalten Vol.4.

Steffensen, Rolf og Langkaas, Randi, 2002. Konfirmantbibelen - Veilederheftet. Oslo: Det Norske Bibelselskap

Tabari, Mahmoud Abdi, Tabari, Iman Abdi, 2015. Links between Bloom's Taxonomy and Gardener's Multiple Intelligences. The issue of Textbook Analysis. Advances in Language and Literary Studies Vol.6, No.1. (url: http://dx.doi.org/10.7575/aiac. alls.v.6n.1p.94; 20.12.2017)

Weinbrenner, Peter, 1992. Methodologies of Textbook Analysis used to date. S.21-34 i: Hillary Bourdillon (red.): History and Social Studies. Methodologies of Textbook Analysis. Amsterdam/Lisse. (European meetings on educational research vol. 27)

Winje, Geir, 2008. Lærebøkene i KRL - hva har skjedd på ti år? S.1-14 i: Norsk teologisk tidsskrift nr. 1/2008

\section{Internett:}

Byfuglien, Helga Haugland: En kirke med rom for ulike syn. Aftenposten 22.04.2016 http://www.aftenposten.no/meninger/kronikk/En-kirke-med-rom-for-ulikesyn--Helga-Haugland-Byfuglien-57364b.html (28.04.2017)

http://Kbibel.no (15.05.2017)

http://Nøklertillivet.no (sic)(28.04.2017)

https://www.ssb.no/kultur-og-fritid/statistikker/kirke_kostra/aar (19.12.2017) 